\title{
CUSTOMER ORIENTED APPROACH FOR DEVELOPMENT OF THE COMPANY
}

\author{
Zoya GELMANOVA, Olga KRIVTSOVA \\ Karaganda State Industrial University, Temirtau, Kazakhstan, \\ zoyakgiu@mail.ru
}

https://doi.org/10.37904/metal.2019.770

\begin{abstract}
The article analyzes the approaches of different authors to understanding the essence of the term "customeroriented". Based on the McKinsey "7C" model, various aspects of the client-oriented approach are demonstrated. A substantial model of customer orientation is proposed on the example of ArcelorMittal Temirtau one of the most important plants in the Asian region for the largest steel company ArcelorMittal International. The model allows, on the one hand, to structure the orientation to the client, and on the other to evaluate this competence in the company. The basic values of client-orientedness are determined. The main approaches of economists to understanding competences and allocation of key competencies are analyzed. The main new competences are proposed the strategic vision in the context of the modern development of the theory of relationship management. The client-oriented strategy of the company is formulated. The reasons and peculiarities of the renaissance of client-oriented behavior of firms in modern conditions of economic re-industrialization are investigated. Within the framework of the conducted research the client-orientation was evaluated, in the interests of achieving the leading positions in the target markets, using the example of ArcelorMittal Temirtau.
\end{abstract}

Keywords: Client, customer, customer orientation, key customer management, key competencies

\section{INTRODUCTION}

In today's business, companies engaged in the creation of a stable competitive position are increasingly moving away from the focus on current sales figures and strive to develop long-term interactions with key market participants, especially with customers. To create a sustainable competitive position the company comes through the construction of a system of partnerships to improve the efficiency of the processes of creation and distribution of value.

We analyze the increased attention to customers in the modern economy, there are several reasons associated with the consequences of scientific and technological progress (NTP), which leads to an increase in the share of consumer goods of complex design and composition, mass production and consumption, an increase in the diversity of the intraspecific range of goods, which further disorients the buyer.

Purpose. The study of customer-oriented approach in the context of modern development of the theory of management of relations between companies and customers

\section{TEORETICAL REVIEW}

For disclosure of client-oriented company image its need to define the term "customer focus". The proposed definition below was formulated after studying organizations that interviewed experts recognized the customeroriented, and the allocation of common characteristics inherent in such an organization $[1,2,3]$.

Customer focus can be understood as self-restraint organization rewards its customers. The company does not go beyond its competence and does not try to satisfy completely all the needs of all its customers, instead concentrating on its core competencies to a limited target group, which is able to establish partnerships. 
Various aspects of the manifestation of customer orientation can be demonstrated on the basis of model McKinsey "7C", which deals with the organization as a system consisting of seven elements, presented in Table 1.

Thus, we can define the following mandatory conditions for the organization applying for customer orientation: the presence of informed and purposefully develop key competences and lack of declarative key general competencies (examples of the latter: the production of quality products at a fair price, the satisfaction of consumer expectations); unambiguous definition of target groups and identifying their unique needs. Ready for the client to refuse diversion key priority service; priority to long-term profits before the short-term benefit. A problem of development is actual and not of survival.

Table 1 Forms of customer focus on the elements of the model McKinsey "7C" [2]

\begin{tabular}{|c|c|c|}
\hline «7C» model element & The essence of the element & Form of customer focus \\
\hline Strategy & $\begin{array}{l}\text { Long-term development plan of the } \\
\text { organization. }\end{array}$ & $\begin{array}{c}\text { Having a strategy enables the organization } \\
\text { to achieve key competencies. }\end{array}$ \\
\hline Structure & $\begin{array}{c}\text { The way of interaction between } \\
\text { departments. }\end{array}$ & $\begin{array}{l}\text { The interaction of the "front office" and } \\
\text { "back office". }\end{array}$ \\
\hline Control system & Methods of managerial decision-making. & The harmonization of rules and procedures. \\
\hline The system of values & $\begin{array}{c}\text { The norms and standards of interaction in } \\
\text { organizations. }\end{array}$ & $\begin{array}{l}\text { The promotion of values of customer focus } \\
\text { among the employees of the organization }\end{array}$ \\
\hline The skill system & $\begin{array}{c}\text { Abilities, potential and competencies } \\
\text { possessed by the staff of the organization }\end{array}$ & $\begin{array}{l}\text { The competencies that are needed to } \\
\text { implement customer-oriented approach }\end{array}$ \\
\hline The staff & $\begin{array}{c}\text { How many employees work in your } \\
\text { organization? Who they are? }\end{array}$ & $\begin{array}{l}\text { The staff is an active participant in } \\
\text { communications. }\end{array}$ \\
\hline $\begin{array}{l}\text { The style of } \\
\text { relationships within the } \\
\text { organization }\end{array}$ & $\begin{array}{c}\text { The management style adopted in the } \\
\text { organization. }\end{array}$ & Customer-oriented style relationship. \\
\hline
\end{tabular}

Among the factors that hinder the organization to become a customer-oriented, include the following: the organization of an aggressive strategy aimed at a substantial increase in market share; focus on short-term profits $[4,5]$.

In some cases, customers do not allow the organization to be customer-oriented. For example, in the case of oligopsony or close to the situation, the customer does not want to put himself in a position equal to the supplier. Significant differences in the extent of the supplier and the client businesses often do not admit the possibility of partnerships. The client, using the fact that the supplier depends from him, "pushes" beneficial only for his interaction conditions, forcing the supplier to refuse customer focus [6,7].

\section{PRACTICAL USE}

At the present stage of development, the metallurgical industry (especially large production having a plurality of both large and small customers) is faced with the problem of quality of service of each of the clients (in most cases there is no customer focus strategy).

Metallurgical enterprises in Europe suggest the concept of a group to work with clients (client-oriented functional unit), which we consider the basic structure below. On the advanced enterprises always raises the question: how to create an effective team of customer support?

To create a customer-oriented group, we must define the following components: the program and objectives of the department / group; appropriate technical experts; management support; selection of the most effective 
model; support / sufficient number of specialists; connection with logistics / order management department; communication with different production departments; interaction means [8,9].

European advanced plants of the company offered to create a group in Temirtau to work with customers, which would bring ArcelorMittal Temirtau to a new level of cooperation with our regular customers both in Europe and in Asia, improving multifaceted relationships at every stage of production, delivery and processing of products.

Group model has been worked out in cooperation with European experts in the field of work with consumers.

The first steps in the creation of the group were as follows: set up a group to work with clients; held a meeting with the ArcelorMittal Gent on the functional and technical characteristics of the group; the basic consumers of the European and East Asian regions; prepared scheme CS interaction with plant services; Join for satisfaction with the quality assessment of products of "ArcelorMittal Temirtau".

According to the approved concept of work group defined its main tasks:

1) Strengthening the connection with regular consumers.

2) Improving customer service. Service provides a personalized relationship with the client, a clear understanding and appreciation of its current and future needs, and this, in turn, keeps the customer and increase its long-term value.

3) Determination of the advantages and disadvantages of our products and the products of competitors, analyzing the data and making recommendations to ensure consumer requirements (compliance with product quality) to obtain information on the products of our competitors and benchmarking with our products, events and issue recommendations to improve our products for the consumer is not satisfied with the performance).

4) The increase in volumes and the expansion of product mix.

At the present stage of development of the steel industry the "quality" term combines the standards, high production inside the plant, which is the careful handling of metal during the preparation metal for shipment, as well as a careful attitude when delivering products by railways, the treatment of the metal in the ports of safe transportation in ships, unloading and storage in the consumer ports.

During 2017 "ArcelorMittal Temirtau" was at the peak of its relations with its European and Asian customers, the most performing shipment volumes, as well as paying close attention to the needs and wishes of customers in the aspect of technology and service products. In order to determine the current state of the quality of steel products of "ArcelorMittal Temirtau" was carried out comprehensive analysis of the comments and suggestions of the East Asian consumers, who at present is the growing segment of steel consumption. The results are shown below. Contact information is provided: Iran, Asia and the Middle East.

To review consumer represents about $20 \%$ of the volume for Temirtau (East Asian market segment) in Table 2.

Table 2 Distribution of feedback [10]

\begin{tabular}{|c|c|c|c|}
\hline Market segment & End consumers & $\begin{array}{c}\text { Wholesale trade/ storage } \\
\text { warehouses }\end{array}$ & $\begin{array}{c}\text { Share on overview } \\
\text { analysis consumers \% }\end{array}$ \\
\hline Iran & $2^{*}$ & $3^{*}$ & 19,57 \\
\hline East Asia & 1 & 2 & 51,79 \\
\hline Near East & 0 & 3 & 21,12 \\
\hline Total amount & 3 & 8 & 100 \\
\hline${ }^{*}$ commerce technology, Iran is taken as the end consumer - trader
\end{tabular}


The survey showed, the priority of the key factors of production to the end consumer and wholesale firms in Table 3.

From Table 3 the analysis implies that end-users and wholesalers give priority to product quality and price, which is the most attractive on the "ArcelorMittal Temirtau".

Table 3 Ranking of the key factors for prioritizing [10]

\begin{tabular}{|l|c|c|}
\hline \multicolumn{1}{|c|}{ Key factor of production purchase } & End consumers & Sellers / firm owners of stocks products \\
\hline Production quality & 1 & 1 \\
\hline Price & 2 & 2 \\
\hline Terms of payment & 3 & 4 \\
\hline Production delivery & 4 & 3 \\
\hline The effectiveness of the relationship & 5 & 5 \\
\hline Technical support & 6 & 7 \\
\hline Pre / after-sales service & 7 & 6 \\
\hline
\end{tabular}

Over the past year, hot-rolled structural steel grades were the most exported to Europe and Asia. In addition to the difficulty of its production in terms of technology, hot-rolled coil has a lot of problems with transportation, which is caused by multiple injuries rolls edge when driving on the shop roller conveyors, crane operations and loading on the vertical axis to cross platforms.

Damaged rolls are primarily concerned with the unsatisfactory winding rolls (telescoping, protruding coils). When processing incoming roll to the shop adjustage bays damaged during transport the coils are removed, that is $400-500 \mathrm{~kg}$ per roll. After processing, the roll is packaged, labeled, weighed and loaded onto the platform (vertical loading scheme). After research we asked to use an additional tighter control of the process of rolling on the Mill-1700 and shipped on the horizontal axis-duty metal (for critical consumers).

The existing (left) and the proposed expanded (right) control scheme / production and shipment of the metal circuit shown in Figure 1, which shows that at each stage of production in the sheet rolling shop №1 there are bottlenecks, control of which is necessary to strengthen and provide feedback between cooperating operational units in order to change the technology to eliminate such a defect coiling as "telescoping" or "protruding coils" that are causing multiple injuries during transport rolls in the shop to the site of processing and loading into wagons.

Because of damage was carried out joint inspection with experts of Operational Excellence Benchmarking metal injury on the stage of delivery to the consumer when used as a shipment on the vertical (VA), and the horizontal axis (HA). The results of the inspections are given in Table 4.

Table 4 Inspection of the state of hot rolled coils in the delivery stages [10]

\begin{tabular}{|c|c|c|c|c|c|c|c|c|}
\hline \multirow{3}{*}{ Indicator } & \multicolumn{8}{|c|}{ Damage accumulation rolls on delivery stages, $\%$} \\
\hline & \multicolumn{2}{|c|}{ Sheet rolling shop №1 } & \multicolumn{2}{|c|}{ Port of Novorossiysk } & \multicolumn{2}{|c|}{ Port of Aveiro } & \multicolumn{2}{|c|}{ Costumer } \\
\hline & VA & HA & VA & HA & VA & HA & VA & HA \\
\hline The coils are hammered / bent & 23 & 10 & 51,2 & 23,7 & 52,2 & 24,1 & 52,2 & 24,1 \\
\hline The coils are crushed & 3.6 & 1.5 & 9.7 & 4.5 & 10.2 & 4.7 & 10.2 & 4.7 \\
\hline The coils are torn & 0.97 & 0.25 & 4.36 & 2.3 & 5.34 & 2.51 & 5.34 & 2.51 \\
\hline Total: & 27.57 & 11.75 & 65.26 & 30.5 & 67.74 & 31.31 & 67.74 & 31.31 \\
\hline Difference between VA and HA & \multicolumn{2}{|c|}{15.82} & \multicolumn{2}{|c|}{34.76} & \multicolumn{2}{|c|}{36.43} & \multicolumn{2}{|c|}{36.43} \\
\hline
\end{tabular}


As follows from the analysis in Table 4, when loading in the Sheet rolling shop №1 on the horizontal axis is reduced by damage of $15.82 \%$, while in the ports of transport operations at $34.76 \%$, in the port of unloading and delivery to the consumer at $36.43 \%$. This clearly indicates that the shipment on a horizontal axis $1 / 3$ of hot metal may be stored in integrity.

We emphasize the importance of the reforms to be carried out in the performance of the company aimed at the client approach. Vector of activity shifted from the "product" process to find the most profitable customer segments and develop retention strategies.

The growing influence of consumers makes it necessary to concentrate all the resources of the company to achieve a single goal - "the creation of customer satisfaction", due to the quality of manufactured products and provided services. The Customers Realtionship Managamenet (CRM) is under the direct management of senior management, and all structural divisions and employees of the company take part in its execution.

Thus, a customer relationship management can be understood as an isolated activity of department on work with clients (CRM in the "narrow" sense), and the integrated activities of all organizational units, aimed at increasing the company's value for its clients and increase client capital (CRM in "wide" sense).

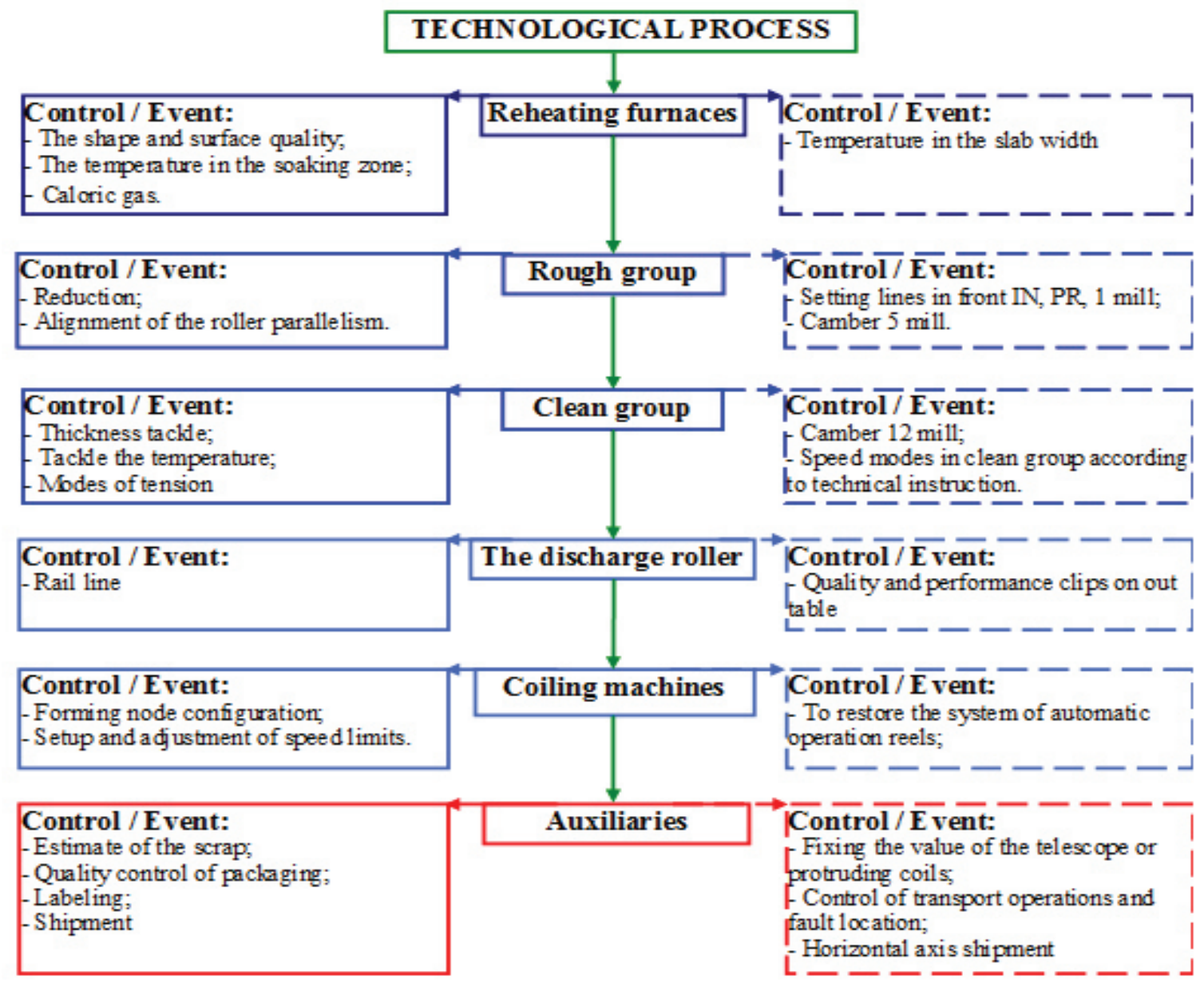

Figure 1 The existing and proposed schemes of products quality control [10]

\section{CONCLUSION}

Thus, through a focus on target customers, using factors: core competence, the unique needs of each target client and equity positions, the company will be able to achieve a leading position, both in the domestic markets 
of Kazakhstan, and foreign international markets in the long-term strategic planning. Confirmation of this hypothesis are the results conducted by private research, which were aimed at identifying the quality parameters of products, allowing to evaluate the technical capabilities of the company to date. Assessment of the degree of satisfaction of requirements of various consumers (end-users, the wholesale company) was made. With the help of an expert assessment has been determined to select the most efficient type of transport for the transportation of goods. Formulated an advanced concept group organization to work with customers (customer-functional unit). On the basis of these results recommendations on strategy have been developed.

\section{REFERENCES}

[1] RYZHKOVSKI B.N. When the customer votes by money. // Company management. - 2005. vol. 7, pp. 42-45.

[2] BUSARKINA V.V. The concept of customer-oriented enterprise and the problems of its evaluation. // Problems of modern economy. - 2007. vol. 4, pp. 18-23.

[3] LOSEV S.V. The principles of client-oriented organization. // Management in Russia and abroad. - 2008. vol. 8, pp. 42-45.

[4] KAREEVA Y.B. Customer orientation: theory and practice. // Methods of quality management. - 2007. - №11. - pp.. 29-33.

[5] LOSHKOV V. Customer focus, what is the point? - URL: http://www.rosbo.ru/articles.php?cat id=2

[6] MANN I. Customer focus: what to do, how to do, take and do. - - URLS [Electronic resource] - Mode of access: http://www.strategy.com.ua/Articles/Content?ld=1478.

[7] SMIRNOV Yu.I. Customer focus as a way to get additional profit. M.: FLINTA, 2013. - $176 \mathrm{p}$.

[8] LUCHKOV V. E. What is customer focus // Business magazine. - 2010. - №19. - pp. 27-30.

[9] REUVENNY I.Y. Customer-oriented approach to organization development // Almanac of modern science and education. - 2015. - №6 (96). - pp. 132-135.

[10] GELMANOVA Z.S. Research methodology of client-oriented strategy of the company ArcelorMittal Temirtau JSC. Monograph. Temirtau: Scientific and technical information center, 2013. p. 147. 